\title{
Trykkmadrasser Forebygger trykksår
}

Trykksår eller liggesår er sår som oppstår på grunn av trykk, friksjon eller opprivende krefter mot huden over lengre tidsperioder. Spesielt utsatte områder er utstikkende beinete områder som hoftene, anklene, hælene, ørene, samt trykkpunkter nederst på ryggen nær halebeinet. Trykksår oppstår når vevet får for dårlig blodtilførsel fordi man sitter eller ligger i samme posisjon over lengre tid, ned mot 60-90 minutter. Disponerende faktorer er undervekt, overvekt, feilernæring, høy alder, nervesykdommer og diabetes. Forekomsten av trykksår varierer i forskjellige populasjoner. Data fra studier i fem europeiske land viste en prevalens på 18 prosent for alle stadier og 10 prosent dersom de mildeste stadier var ekskluderte.

Å forebygge trykksår er en sentral sykepleieoppgave. Samarbeidet for Sykepleiere i Norden har valgt ut trykksår som én av flere sykepleiesensitive kvalitetsindikatorer. Denne indikatoren er aktuell for mange spesialiteter og diagnoser.
Hensikten med denne systematiske oversikten var å vurdere effekten av ulike støtteunderlag, puter, senger, madrasser og overmadrasser sammenlignet med standard puter og madrasser på forekomsten av trykksår. Hvor effektive er de forskjellige typer puter eller madrasser sammenlignet med hverandre?

\section{HVA SIER FORSKNINGEN?}

Forfatterne fant totalt 52 studier.

- Studiene viste at forekomsten av trykksår kan reduseres ved bruk av trykkavlastende madrasser, puter eller saueskinnspels

- Madrasser som alternerer trykk kan være kostnadseffektive

- Bruk av vanlige skumgummimadrasser kan øke forekomsten av trykksår

\section{HVA ER DENNE INFORMASJO- NEN BASERT PÅ?}

Forskere i Cochrane-samarbeidet har oppdatert en oversikt over randomiserte studier som har undersøkt effekten av ulike typer puter, madrasser og underlag som skal forebygge trykksår. Forskerne gjorde systematiske søk i flere forskningsdatabaser, og fant 52 studier som de inkluderte i oversikten. Studiene var gjennomført i alle typer settinger.

\section{KILDE}

McInnes E, Cullum NA, Bell-Syer SEM, Dumville JC, Jammali-Blasi A. Support surfaces for pressure ulcer prevention. Cochrane Database of Systematic Reviews. 2008, Issue 4. Art. No.: CD001735. DOI: 10.1002/14651858.CD001735.pub3.

Skrevet av Liv Merete Reinar, Nasjonalt kunnskapssenter for helsetjenesten

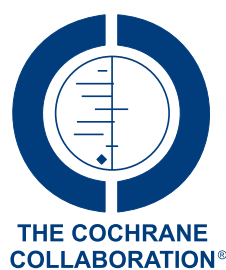


MEN MAMMA! HUIS JEG LE66ER MEG ALLEREDE NÄ, KAN JEG JO STÁ I FARE FOR A UTVIKLE TRYKKSAR!
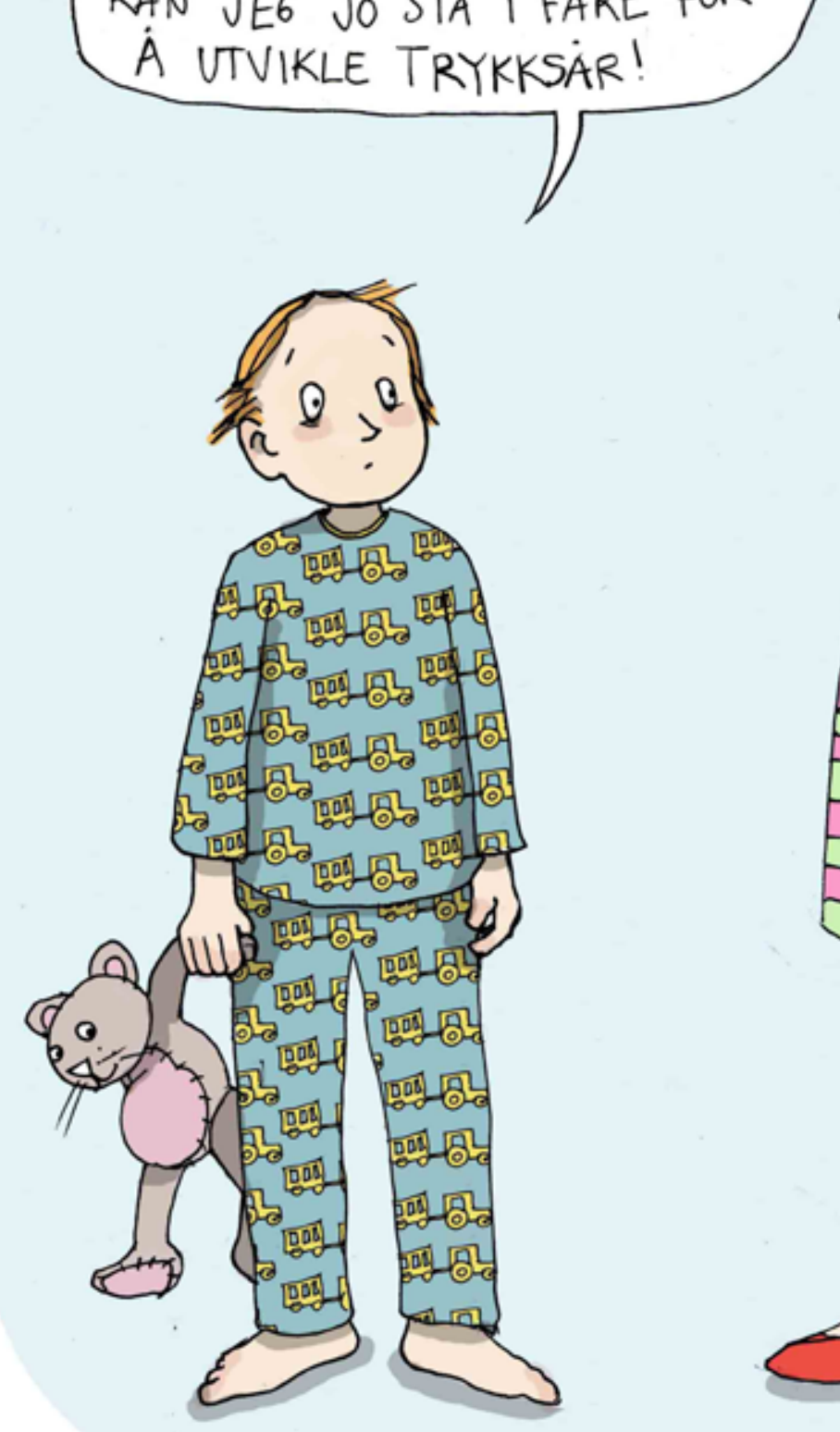